\title{
Molecular survey of Anaplasma platys and Ehrlichia canis in dogs from Campo Grande, Mato Grosso do Sul, Brazil
}

\author{
RODRIGO SOARES ${ }^{1}$, CARLOS ALBERTO RAMOS ${ }^{1}$, THATIANNA PEDROSO ${ }^{2}$, VERÔNICA \\ BABO-TERRA ${ }^{1}$, HERBERT CLEVELAND ${ }^{3}$ and FLÁBIO DE ARAÚJO ${ }^{4}$ \\ ${ }^{1}$ Faculdade de Medicina Veterinária e Zootecnica, Universidade Federal de Mato Grosso do Sul, \\ Avenida Senador Filinto Muller, 2443, 79074-460 Campo Grande, MS, Brazil \\ ${ }^{2}$ Diagno Vet Laboratório Veterinário, Rua Manoel Inácio de Souza, 1053, 79021-190 Campo Grande, MS, Brazil \\ ${ }^{3}$ Laboratório de Biologia Molecular, Faculdade de Medicina Veterinária e Zootecnica, Universidade Federal \\ de Mato Grosso do Sul, Avenida Senador Filinto Muller, 2443, 79074-460 Campo Grande, MS, Brazil \\ ${ }^{4}$ Embrapa Gado de Corte, Avenida Rádio Maia, 830, 79106-550 Campo Grande, MS, Brazil
}

Manuscript received on July 29, 2015; accepted for publication on September 15, 2016

\begin{abstract}
This study investigated the frequency of infection by Anaplasma platys and Ehrlichia canis in dogs submitted to animal health centers in Campo Grande, state of Mato Grosso do Sul, Brazil. E. canis and A. platys showed infection frequencies of $55.75 \%$ and $16.96 \%$, respectively. The identity of the two species was confirmed by DNA sequencing.
\end{abstract}

Key words: epidemiology, nPCR, DNA, Midwestern Brazil.

\section{INTRODUCTION}

Anaplasma platys and Ehrlichia canis are Gram-negative, obligatory intracellular bacteria and members of the Anaplasmataceae family (Dumler et al. 2001). These organisms are often found in dogs, commonly infecting platelets and leukocytes, forming colonies called morulae. Ehrlichia organisms are mainly transmitted through the bite of an infected tick. This explains the higher prevalence of ehrlichiosis in tropical and subtropical regions due to the geographical distribution of vectors (Andereg and Passos 1999). E. canis, which is mostly transmitted by Rhipicephalus sanguineus (Groves et al. 1975),

Correspondence to: Carlos Ramos

E-mail: carlos.nascimento@ufms.br has been detected throughout Brazil (Oliveira et al. 2009, Ueno et al. 2009). E. canis infection in Brazil was reported for the first time in 1973 (Costa et al. 1973). Although the disease is currently described nationwide, prevalence data differ with respect to population, geographic area, presence of the vector and the diagnostic test employed. The presence of known competent tick vectors as well as reservoir hosts usually determines where ehrlichiosis is found (Moraes-Filho et al. 2015).

Rhipicephalus sanguineus is widespread in Brazil (Labruna and Pereira 2001) and can also transmit other dog blood parasites such as Babesia canis, Babesia vogeli, Babesia rossi, Rickettsia spp, Hepatozoon canis, H. americanum among others (Dantas-Torres 2008, Kamani et al. 2013, René-Martellet et al. 2015). 
E. canis-infected dogs and co-infected with Anaplasma sp. are frequently found (Dagnone et al. 2009, Ramos et al. 2010). Anaplasma platys causes the so-called canine cyclic thrombocytopenia. Dogs are the primary reservoir host for A. platys, although this organism has been shown to infect humans (Maggi et al. 2013, Arraga-Alvarado et al. 2014). A. platys infections are often found in the same geographic regions as E. canis and evidence of exposure to or infection with both organisms is often detected in the same dog (Harrus et al. 1997, Gal et al. 2008, Cardoso et al. 2010, Diniz et al. 2010, Aktas et al. 2015). Although both organisms are found on every continent in the world, they are more prevalent in tropical and subtropical climates (Stich et al. 2008, Yabsley et al. 2008).

Several methods with varying degrees of sensitivity and specificity can be used to detect Ehrlichia and Anaplasma organisms. They are usually identified using light microscopy to identify elementary bodies, initial bodies or morulae in the host-cell cytoplasm of Romanowsky-stained blood smears (Hildebrandt et al. 1973). However, this technique unfortunately lacks sensitivity and specificity. Diagnostic accuracy has been greatly enhanced by the introduction of culture and molecular techniques.

These bacteria are among the blood cell parasites most frequently diagnosed in dogs in various regions of Brazil (Ramos et al. 2010, Lasta et al. 2013), but there are few reports about the quantitative frequency of infection by these organisms in dogs in Campo Grande, State of Mato Grosso do Sul (MS), detected mainly by molecular tools (Dagnone et al. 2009, Souza et al. 2013). Due to the zoonotic potential of these infectious agents, their accurate identification and genetic characterization in dogs is important, as it allows one to estimate the risk of transmission to humans and to identify the presence of genetic variants best adapted to a specific host.
Thus, the aim of this study was to use polymerase chain reaction (PCR) to estimate the frequency of infection by $A$. platys and $E$. canis in dogs submitted to veterinary clinics and hospitals in Campo Grande, Mato Grosso do Sul, in the period from 2007 to 2009. And also to assess the genetic similarity, based on 16S rRNA gene, between local microorganisms found (Campo Grande, MS) and the bacteria (A. platys and E. canis) identified in other regions.

\section{MATERIALS AND METHODS}

A non-probability sample was obtained by collecting blood from 181 dogs submitted to veterinary clinics in the municipality of Campo Grande, MS, from 2007 to 2009, exhibiting pale mucous membranes, fever, loss of appetite, as well as presence or prior history of tick infestation. The samples were drawn into tubes containing EDTA and stored at $-16^{\circ} \mathrm{C}$ for subsequent DNA extraction using the methodology described by Araújo et al. (2009). The integrity and concentration of the DNA samples extracted in $1 \%$ agarose gel stained with SYBR Gold (Invitrogen) were assessed, respectively, by electrophoresis and spectrophotometry $(260 / 280 \mathrm{~nm})$.

To eliminate the possibility of obtaining false negative results due to the presence of PCR inhibitors in DNA samples, all the samples were subjected to PCR with primers for the canine $\beta$-actin gene, as described by Wang et al. (2007).

Nested PCR reactions for $A$. platys and $E$. canis were conducted following the methodologies described by Martin et al. (2005) and Wen et al. (1997), respectively. Samples were considered positive when specific band sizes were observed (678 bp for A. platys and 389 bp for E. canis) after electrophoresis.

For the genetic analysis, five animals positive for each pathogen were randomly selected. Amplified fragments were purified using a QIAEX II kit (Qiagen) and sequenced in both directions 
in an ABI-3130 automated sequencer (Applied Biosystems). Three sequences were made of each sample, and a consensus sequence was built using the SEQUENCHER v 4.1.4 program (Gene Codes). The consensus sequences (514 bp for $A$. platys and 388 bp for $E$. canis) were then subjected to a homology search using the BLASTn program (Altschul et al. 1990). The consensus sequence of each bacterium was deposited in the NCBI GenBank database.

\section{RESULTS AND DISCUSSION}

Among the 181 samples collected, 108 (59.66\%) were positive for E. canis, 28 (15.46\%) for A. platys, and 18 animals $(9.94 \%)$ showed co-infection by the two agents. All the samples showed amplification for the canine constitutive gene $\beta$-actin (237 bp), confirming the absence of PCR inhibitors in the samples.

The frequencies of infection by E. canis and $A$. platys in dogs, assessed by molecular tools, varied according to the region and population under study. Canine monocytic ehrlichiosis, the disease caused by infection with $E$. canis, is endemic in Brazil and highly prevalent among dogs throughout the country (Vieira et al. 2011). Nevertheless, in a study in the southern region of Brazil (Porto Alegre, RS), Lasta et al. (2013) found a frequency of $14.07 \%$ of dogs infected by $A$. platys and no animal infected by $E$. canis out of 199 homeless or partly domiciled animals.

In another study, prevalence of E. canis infection in dogs from different areas and from selected hospital populations in southeastern Brazil ranged from 15\% (Macieira et al. 2005) to $44.7 \%$ (Costa Jr et al. 2007). In general, higher frequencies of infection are expected in regions where the tick vector is more abundant, such as Campo Grande, MS (Almeida et al. 2013), in relation to regions with lower infestation rate by ticks, such as Porto Alegre, Rio Grande do Sul, Brazil (Ribeiro et al.
1997). On the other hand, in some regions with high rates of tick infestation, such as Mato Grosso (Almeida et al. 2012), small frequencies of $E$. canis infection have been found $(15.6 \%$ of dogs from urban area, and $14.4 \%$ of dogs from rural area) (Santos et al. 2013). In addition, in a previous serological survey conducted by Melo et al. (2011), $74.3 \%$ of dogs from urban areas and $67.5 \%$ from rural areas showed antibodies against E. canis. The presence of $R$. sanguineus ticks on the dogs studied was not considered a risk factor for $E$. canis infection (Melo et al. 2011).

Thus, it is evident that factors other than tick infestation rate have been associated to the frequency of infection by E. canis and possibly other Rickettsiaceae. For example, Nava et al. (2012) have observed genetic divergence between different strains of $R$. sanguineus from South America. In a recent study, Moraes-Filho et al. (2015) has observed that some of these strains showed different levels of vector competence for E. canis, allowing us to conclude that not only the presence but also the vector competence of the tick strain influence the prevalence of the agent in a region.

In a recent study conducted in Campo Grande, MS, using 60 dogs serologically positive for Leishmania infantum, the frequency of infection with E. canis was $45 \%$, and only $1.6 \%$ with Anaplasma sp., using PCR (Souza et al. 2013), which again illustrates the higher frequency of infection in this municipality.

However, when sampling involves animals submitted to veterinary clinics and hospitals, which represent points of convergence of sick individuals, frequencies of infection of up to $48.78 \%$ have been recorded for $A$. platys and of $38.04 \%$ for $E$. canis, according to Ramos et al. (2010). These authors analyzed 205 samples from dogs treated at a veterinary hospital in the city of Recife, Pernambuco. Dagnone et al. (2009) reported similar findings (42.30\% for A platys and $38.46 \%$ for $E$. canis) among 26 animals treated at a veterinary 
RODRIGO SOARES et al.

hospital in the city of Campo Grande, MS. In the present study the percentage of infected animals was also high $(59.66 \%$ for E. canis), since the samples were obtained from sick dogs at veterinary clinics.

The DNA sequences obtained in this study were deposited at GenBank under access numbers JX118827 (E. canis) and JX118826 (A. platys). A search for homology using the BLASTn tool indicated that all the sequences (E. canis and $A$. platys) showed 99 to $100 \%$ identity with their respective DNA sequences deposited in GenBank, thus confirming the specificity of the nested PCR used here.

The high frequency of dogs infected with these bacteria indicates a high tick infestation, especially by $R$. sanguineus, which is their main vector in urban areas (Almeida et al. 2013). In addition, the proximity between humans and dogs, and the possibility of human tick infestation, according to several reports in Brazil (Dantas-Torres et al. 2006, Louly et al. 2006), and in other regions of the world (Carpenter et al. 1990, Felz et al. 1996, Manfredi et al. 1999, Uspensky and Ioffe-Uspensky 2002) represent possible risk factors for human infection with E. canis and A. platys. Several reports of human infection with $A$. platys have been published (Maggi et al. 2013, Breitschwerdt et al. 2014), including in South America (Arraga-Alvarado et al. 2014).

Data obtained in this report corroborate previous studies from several parts of Brazil that reported high frequencies of $E$. canis infection in dogs, and also confirmed that the Ehrlichia species that is circulating among dogs from Campo Grande, Mato Grosso do Sul is Ehrlichia canis.

\section{REFERENCES}

AKTAS M, ÖZÜBEK1 S, ALTAY K, IPEK NDS, BALKAYA I, UTUK AE, KIRBAS A, ȘIMSEK S AND DUMANL N. 2015. Molecular detection of tick-borne rickettsial and protozoan pathogens in domestic dogs from Turkey. Parasite Vectors 8: 157.
ALMEIDA ABPF, DE PAULA DAJ, DAHROUG MAA, FREITAS AG, SILVA JN, DUTRA V, NAKAZATO L AND SOUSA VRP. 2012. Ehrlichia canis e Anaplasma platys em carrapatos de cães de Cuiabá, Mato Grosso. Semina: Ciências Agrárias 33: 1123-1126.

ALMEIDA RFC, GARCIA MV, CUNHA RC, MATIAS J, SILVA EA, MATOS MFC AND ANDREOTTI R. 2013 Ixodid fauna and zoonotic agents in ticks from dogs: first report of Rickettsia rickettsii in Rhipicephalus sanguineus in the state of Mato Grosso do Sul, mid-western Brazil. Exp Appl Acarol 60: 63-72.

ALTSCHUL SF, GISH W, MILLER W, MYERS EW AND LIPMAN DJ. 1990. Basic local alignment search tool. J Mol Biol 215: 403-410.

ANDEREG PI AND PASSOS LMF. 1999. Erliquiose caninaRevisão. Clin Vet 4: 31-38.

ARAÚJO FR, RAMOS CAN, LUIZ HL, PÉREZ IAHFS, OLIVEIRA RHM, SOUZA IIF AND RUSSI LS. 2009. Avaliação de um protocolo de extração de DNA genômico a partir de sangue total. Embrapa Gado de Corte, 5. (Embrapa Gado de corte. Comunicado Técnico, 120).

ARRAGA-ALVARADO CM, QUROLLO BA, PARRA OC, BERRUETA MA, HEGARTY BC AND BREITSCHWERDT EB. 2014. Case report: Molecular evidence of Anaplasma platys infection in two women from Venezuela. Am J Trop Med Hyg 91: 1161-1165.

BREITSCHWERDT EB, HEGARTY BC, QUROLLO BA, SAITO TB, MAGGI RG, BLANTON LS AND BOUYER DH. 2014. Intravascular persistence of Anaplasma platys, Ehrlichia chaffeensis, and Ehrlichia ewingii DNA in the blood of a dog and two family members. Parasit Vectors 7: 298.

CARDOSO L, TUNA J, VIEIRA L, YISASCHAR-MEKUZAS Y AND BANETH G. 2010. Molecular detection of Anaplasma platys and Ehrlichia canis in dogs from the North of Portugal. Vet J 183: 232-233.

CARPENTER TL, MCMEANS MC AND MCHUGH CP. 1990. Additional instances of human parasitism by the brown dog tick (Acari: Ixodidae). J Med Entomol 27: 1065-1066.

COSTA JO, BATISTA JÚNIOR JA, SILVA M AND GUIMARÃES PM. 1973. Ehrlichia canis infection in a dog in Belo Horizonte-Brazil. Arq Bras Med Vet Zootec 25: 199-200.

COSTA JR LMC, REMBECK K, RIBEIRO MF, BEELITZ P, PFISTER K AND PASSOS LM. 2007. Seroprevalence and risk indicators for canine ehrlichiosis in three rural areas of Brazil. Vet J 174: 673-676.

DAGNONE AS, SOUZA AI, ANDRÉ MR AND MACHADO RZ. 2009. Molecular diagnosis of Anaplasmataceae organisms in dogs with clinical and microscopical signs of ehrlichiosis. Rev Bras Parasitol Vet 18: 20-25. 
DANTAS-TORRES F, FIGUEREDO LA AND BRANDÃOFILHO SP. 2006. Rhipicephalus sanguineus (Acari: Ixodidae), the brown dog tick, parasitizing humans in Brazil. Rev Soc Bras Med Trop 39: 64-67.

DANTAS-TORRES F. 2008. The brown dog tick, Rhipicephalus sanguineus (Latreille, 1806) (Acari: Ixodidae): From taxonomy to control. Vet Parasitol 152: 173-185.

DINIZ PP ET AL. 2010. High prevalence of tick-borne pathogens in dogs from an Indian reservation in northeastern Arizona. Vector Borne Zoonotic Dis 10: 117123.

DUMLER JS, BARBET AF, BEKKER CPJ, DASCH GA, PALMER GH AND RAY SC. 2001. Reorganization of genera in the families Rickettsiaceae and Anaplasmataceae in the order Rickettsiales: unification of some species of Ehrlichia with Anaplasma, Cowdria with Ehrlichia and Ehrlichia with Neorickettsia, descriptions of six new species combinations and designation of Ehrlichia equi and "HGE agent" as subjective synonyms of Ehrlichia phagocytophila. Int J Syst Evol Microbiol 5: 2145-2165.

FELZ MW, DURDEN LA AND OLIVER JH JR. 1996. Ticks parasitizing humans in Georgia and South Carolina. J Parasitol 82: 505-508.

GAL A, LOEB E, YISASCHAR-MEKUZAS Y AND BANETH G. 2008. Detection of Ehrlichia canis by PCR in different tissues obtained during necropsy from dogs surveyed for naturally occurring canine monocytic ehrlichiosis. Vet J 175: 212-217.

GROOVES MG, DENNIS GL, AMYX HL AND HUXSOLL DL. 1975. Transmission of Ehrlichia canis to dogs by ticks (Rhipicephalus sanguineus). Am J Vet Res 36: 937-940.

HARRUS S, AROCH I, LAVY E AND BARK H. 1997. Clinical manifestations of infectious canine cyclic thrombocytopenia. Vet Rec 141: 247-250.

HILDEBRANDT PK, CONROY JD, MCKEE AE, NYINDO MB AND HUXSOLL DL. 1973. Ultrastructure of Ehrlichia canis. Infect Immun 7: 265-271.

KAMANI J, BANETH G, MUMCUOGLU KY, WAZIRI NE, EYAL O, GUTHMANN Y AND HARRUS S. 2013. Molecular detection and characterization of tick borne pathogens in dogs and ticks from Nigeria. Plos Negl Trop Dis 7(3): e2108.

KORDICK SK, BREITSCHWERDT EB, HEGARTY BC, SOUTHWICK KL, COLITZ CM, HANCOCK SI, BRADLEY JM, RUMBOUGH R, MCPHERSON JT AND MACCORMACK JN. 1999. Co-infection with multiple tick-borne pathogens in a Walker Hound kennel in North Carolina. J Clin Microbiol 37: 2631-2638.

LABRUNA MB AND PEREIRA MC. 2001. Carrapato em cães no Brasil. Clin Vet 6: 24-32.

LASTA CS, DOS SANTOS AP, MESSICK JB, OLIVEIRA ST, BIONDO AW, VIEIRA RFC, DALMOLIN ML
AND GONZÁLEZ FHD. 2013. Molecular detection of Ehrlichia canis and Anaplasma platys in dogs in Southern Brazil. Rev Bras Parasitol Vet 22: 360-366.

LOULY CCB, FONSECA IN, OLIVEIRA VF AND BORGES LMF. 2006. Ocorrência de Rhipicephalus sanguineus em trabalhadores de clínicas veterinárias e canis, no município de Goiânia, GO. Cienc Anim Bras 7: 103-106.

MACIEIRA DB, MESSICK JB, CERQUEIRA AM, FREIRE IM, LINHARES GF, ALMEIDA NK AND ALMOSNY NR. 2005. Prevalence of Ehrlichia canis infection in thrombocytopenic dogs from Rio de Janeiro, Brazil. Vet Clin Pathol 34: 44-48.

MAGGI RG, MASCARELLI PE, HAVENGA LN, NAIODOO V AND BREITSCHWERDT EB. 2013. Co-infection with Anaplasma platys, Bartonella henselae and Candidatus Mycoplasma haematoparvum in a veterinarian. Parasit Vectors 6: 103.

MANFREDI MT, DINI V, PIACENZA S AND GENCHI C. 1999. Tick species parasitizing people in an area endemic for tick-borne diseases in north-western Italy. Parassitologia 41: 555-560.

MARTIN AR, BROWN GK, DUNSTAN RH AND ROBERTS TK. 2005. Anaplasma platys: an improved PCR for its detection in dogs. Exp Parasitol 109: 176-180.

MELO ALT, MARTINS TF, HORTA MC, MORAESFILHO J, PACHECO RC AND LABRUNA MB. 2011. Seroprevalence and risk factors to Ehrlichia spp. and Rickettsia spp. in dogs from the Pantanal Region of Mato Grosso State, Brazil. Ticks and Tick Borne Dis 2: 213-218.

MORAES-FILHO J, KRAWCZAK FS, COSTA FB, SOARES JF AND LABRUNA MB. 2015. Comparative evaluation of the vector competence of four south american populations of the Rhipicephalus sanguineus group for the bacterium Ehrlichia canis, the agent of canine monocytic ehrlichiosis. PLoS One 10: e0139386.

NAVA S, MASTROPAOLO M, VENZAL JM, MANGOLD AJ AND GUGLIELMONE AA. 2012. Mitochondrial DNA analysis of Rhipicephalus sanguineus sensu lato (Acari: Ixodidae) in the Souther Cone of South America. Vet Parasitol 190: 547-555.

OLIVEIRA LP, CARDOZO GP, SANTOS EV, MANSUR MA, DONINI IA, ZISSOU VG, ROBERTO PG AND MARINS M. 2009. Molecular analysis of the rRNA genes of Babesia spp and Ehrlichia canis detected in dogs from Ribeirão Preto, Brazil. Braz J Microbiol 40: 238-240.

RAMOS R, RAMOS C, ARAUJO F, OLIVEIRA R, SOUZA I AND PIMENTEL D. 2010. Molecular survey and genetic characterization of tick-borne pathogens in dogs in metropolitan Recife (north-eastern Brazil). Parasitol Res 107: 1115-1120.

RENÉ-MARTELLET M, MORO CV, CHÊNE J, BOURDOISEAU G, CHABANNE L AND MAVINGUI P. 2015. Update on epidemiology of canine babesiosis in Southern France. BMC Vet Res 11: 223. 
RIBEIRO VLS, WEBER MA, FETZER LO AND VARGAS CRB. 1997. Espécies e prevalência das infestações por carrapatos em cães de rua da cidade de Porto Alegre, RS, Brasil. Cienc Rural 27: 285-289.

SANTOS LGF, MELO ALT, MORAES-FILHO J, WITTER R, LABRUNA MB AND AGUIAR DM. 2013. Molecular detection of Ehrlichia canis in dogs from the Pantanal of Mato Grosso State, Brazil. Rev Bras Parasitol Vet 22: 114118.

SOUZA KCM, ANDRÉ MR, HERRERA HM, ANDRADE GB, JUSI MMG, SANTOS LL, BARRETO WTG, MACHADO RZ AND OLIVEIRA GP. 2013. Molecular and serological detection of tick-borne pathogens in dogs from an area endemic for Leishmania infantum in Mato Grosso do Sul, Brazil. Rev Bras Parasitol Vet 22: 525-531.

STICH RW, SCHAEFER JJ, BREMER WG, NEEDHAM GR AND JITTAPALAPONG S. 2008. Host surveys, ixodid tick biology and transmission scenarios as related to the tick-borne pathogen, Ehrlichia canis. Vet Parasitol 158: 256-273.

UENO TE, AGUIAR DM, PACHECO RC, RICHTZENHAIN LJ, RIBEIRO MG, PAES AC, MEGID J AND LABRUNA MB. 2009. Ehrlichia canis em cães atendidos em hospital veterinário de Botucatu, Estado de São Paulo, Brasil. Rev Bras Parasitol Vet 18: 57-61.

USPENSKY I AND IOFFE-USPENSKY I. 2002. The dog factor in brown dog tick Rhipicephalus sanguineus (Acari: Ixodidae) infestations in and near human dwellings. Int J Med Microbiol 291: 156-163.

VIEIRA RF ET AL. 2011. Ehrlichiosis in Brazil. Rev Bras Parasitol Vet 20: 1-12.

WANG YS, CHI KH AND CHU RM. 2007. Cytokine profiles of canine monocyte-derived dendritic cells as a function of lipopolysaccharide or tumor necrosis factor-alpha-induced maturation. Vet Immunol Immunopathol 118: 186-198.

WEN B, RIKIHISA Y, MOTT JM, GREENE R, KIM HY, ZHI N, COUTO GC, UNVER A AND BARTSCH R. 1997. Comparison of nested PCR with imunofluorescent antibody assay for detection of Ehrlichia canis infection in dogs treated with doxycycline. J Clin Microbiol 35: 18521855.

YABSLEY MJ ET AL. 2008. Prevalence of Ehrlichia canis, Anaplasma platys, Babesia canis vogeli, Hepatozoon canis, Bartonella vinsonii berkhoffii, and Rickettsia spp. in dogs from Grenada. Vet Parasitol 151: 279-285. 